\title{
Application of Stratified Teaching in Middle School/Junior High English Reading Class
}

\author{
Ruixue $\mathrm{Li}^{1, \mathrm{a}}$ \\ ${ }^{1}$ School of foreign languages, Nanjing Normal University Taizhou college, Taizhou, Jiangsu, 215300, China \\ ${ }^{a}$ Corresponding author. Email: gaoming@cas-harbour.org
}

\begin{abstract}
This paper expounds the application of multi-level teaching in junior middle school English class from the perspective of teachers through theoretical and practical analysis. Is the essence of the layered teaching mode according to their aptitude, in view of the different education to measure students' individual differences, give full play to the guiding role of the teacher, in the junior middle school English reading teaching teachers should pay attention to reflect the teaching idea of respect for individual differences, in English reading teaching should take good care of each student's learning situation, so as to stimulate students' learning enthusiasm, improve the level of junior high school students' overall reading. In the process of the study, the relevant theories and practical experience are briefly analyzed, combined with the author's internship experience in Zhibao Middle School in Taizhou City, Jiangsu Province, in order to provide useful reference for relevant educators. During this period, two cases were collected respectively, which were the results of two English teachers adopting different teaching methods in grade two. The overall performance of the class taught by the teacher who often used the stratified teaching method was slightly higher than that of the class who adopted the traditional teaching method. Therefore, applying stratified teaching method in junior middle school English reading teaching can promote the improvement of students' English quality. Reading training for junior high school students can cultivate their good English reading habits and form good reading skills, thus improving their reading interest.
\end{abstract}

Keywords: China, stratified teaching, education method, English Reading class

\section{INTRODUCTION}

Stratified teaching first appeared in the United States in the early 20th century. In order to educate new students with diverse backgrounds, American education officials thought it was necessary to classify them according to their ability and previous academic achievements (stratification). By the 1950s, almost all primary and secondary schools were sorting students into different classes according to ability and staying in the same class for all subjects. However, it has also been criticized for reinforcing racial inequalities and discriminating against students at different levels, resulting in discrimination against "low-functioning children" and physical and mental harm, while giving special treatment to "high-functioning children" and encouraging their arrogance and arrogance. At the same time, due to stratification, the estrangement between students deepens, and it is easy to cause social contradictions, which is an undemocratic form of teaching organization. Thus, stratified teaching fell into a trough. In the 1990s, due to the us government's emphasis on elite talent and academic achievement, most schools returned to the practice of stratified teaching.

Since the 1980s, the concept of stratified teaching has been introduced in China. Schools in various provinces and cities in China have carried out research and practice of stratified teaching, with some successful and some unsuccessful examples. In the process of implementing multi-level English teaching, many experiences and practices worth popularizing and learning have been summarized. For example, the educational experiment of stratified English teaching in Beijing No. 11 Middle School achieved remarkable results and had a great influence at that time.

The combination of "stratified teaching" and "small class" teaching in the United States can give more play to students' autonomy. In foreign countries, there are various forms of stratified teaching, including basic classes, advanced classes and so on, and the formation 
of the elective system of taking classes. However, most of the schools in China are overloaded with large classes, which is caused by the large population base in China and the long-term living of students and teachers in an educational environment dominated by examoriented education. A blindly copy is not feasible for the foreign hierarchical teaching model. Therefore, it is worth exploring how to implement stratified teaching in China according to local conditions.

\section{THE PROCESS AND KEY POINTS OF STRATIFIED TEACHING}

Stratified teaching mode of classroom teaching is mainly divided into the following four stages. The first is the stratified design preview goal before class. The teacher should give appropriate guidance to the students before they preview the teaching material and ask them different levels of requirements and questions. For example, when students study dialogues and essays, they record problems in the preview. I require that students with good foundation can use reference books or online resources to preliminarily solve problems, read and even recite dialogues or passages. Students with poor foundation can memorize new words or sentences containing new words, combine sentences to remember the meaning of new words, and read dialogues or passages fluently. The teaching mode of "stratified interaction" is actually a kind of classroom teaching strategy. The "stratification" here is a kind of implicit stratification. Firstly, teachers should master the learning status, knowledge level, specialties, hobbies and social environment of each student in the class through investigation and observation, and group the students according to their psychological characteristics to form a study group. The use of group cooperative learning and the form of mutual help and learning among members, which is stratified from the students, can give full play to the interaction and incentive between teachers and students, and create opportunities for the overall development of each student. In particular, the interpersonal interaction among students makes use of the differences and cooperative consciousness of students, forming a collective force conducive to the coordinated development of each member. Using the same teaching material and different teaching methods in class to achieve stratified goals; In classroom activities, teachers set different learning objectives for students at different levels and guide them in different learning activities. Students express their opinions during self-study and communication. For example, when learning texts, students with poor foundation should be able to recite key sentence patterns and read the texts fluently. Students with good foundation should not only be able to recite passages, but also be able to retell or rewrite them. Assign homework after class to consolidate learning results. As an extension of classroom teaching activities, homework helps students further understand and consolidate the knowledge of textbooks and conduct ability training. In this process, teachers should arrange homework according to students' own learning ability. For example, good students are required to write dialogues or retell the text, and poor students can translate sentences or recite short paragraphs.

The advantage of stratified teaching for teachers is that they can better understand their students. Teachers can try to prepare learning content for students at the same level, instead of considering students at all levels as before stratified teaching, which increases the degree of distraction and leads to low teaching efficiency. Because of this stratified teaching mode, the learning level of students at the same level is basically the same. Therefore, the teacher does not have to repeat the same knowledge point in the lecture. There is no need for teachers to take care of students with academic excellence as well as those with learning difficulties.

\section{THEORIES RELATED TO STRATIFIED TEACHING}

The application of stratified teaching has certain theoretical basis. Including the zone of proximal development theory and 'I 1 ' 'theory. Stratified teaching adheres to the principle of facing all students. According to the knowledge level and acceptance ability of students at different levels, teaching plans of different levels are designed and different teaching methods are adopted. Teaching is based on "layers", so the teaching content can better suit the requirements of each student.

\subsection{Zone of immediate development theory}

According to the "zone of immediate development" theory, stratified teaching can make the best development of each student. For the top students, can fully develop their own personality, can maximize their own inner potential; For learning difficulties. Teachers can start from the non-intellectual factors of education, stimulate the enthusiasm of learning, from their actual situation, for them to "tailor" suitable for their understanding and acceptance level of knowledge content, so that they have an interest in learning this subject, to achieve the goal of gradually improving their academic performance. The former Soviet Union educator and outstanding psychologist Vygortsky's "zone of proximal development" theory believes that every student has two levels of development: one is the current level, the other is the potential level, the area between them is called "zone of proximal development" or "best teaching area". The area of proximal development closely links teaching and development, highlighting the promotion of teaching to development, the dominant role of teachers, and the importance of cooperative learning [2]. Only from the individual 
differences of these two levels, can the teaching transform the area of proximal development into the current level of development, and constantly create a higher level of the area of proximal development, to promote the development of students. And put forward "teaching must go ahead of development, promote the development of students, such teaching is good teaching" and every student has the need and potential to succeed. Multi-level teaching is aimed at all students, focusing on developing the potential of each student, making teaching requirements suitable for the "recent development zone" of students at each level, creating various conditions and opportunities for students at different levels to try, explore, discover and develop, so that students can gain success and confidence in learning. Therefore, stratified teaching can stimulate students' learning motivation and maximize their enthusiasm, initiative and creativity.

\subsection{I+1 theory}

I+1 theory was put forward by Krashen, an American psychologist and educator in the 1980s. "I" stands for the learner's current language knowledge level, and "1" stands for the gap between the learner's current language knowledge state and the next stage [3]. Krashen believed that the input of language information should not be equal to the current level, "I" should not be far beyond the current level of learners. Therefore, the effective input of understandable input can only be greater than "I" and less than "I+1". The input language information can neither far exceed the learners' current level nor be equal to their current level, that is, "I". One of a series of hypotheses on second language acquisition proposed by Krashen: Human language is the understanding of information, namely by absorbing comprehensible input for language knowledge, therefore, teachers in classroom teaching to students' linguistic information neither too hard, do not be too easy, in the process of layering teaching, it requires teachers according to students' current ability and level, selectively professor knowledge. It should not exceed the scope of students' understanding, but match the students' current learning ability. Krashen uses "I+1". I refers to the current language level of the student, and I+1 refers to the level that the student should reach in the next stage, that is, slightly higher than his current level, so that he can understand the information of $\mathrm{I}+1$ through the context, other contexts, teaching AIDS, PPT and other non-verbal means, so as to master the language structure contained in the information.

\section{CURRENT SITUATION AND ANALYSIS OF ENGLISH READING CLASS IN JUNIOR HIGH SCHOOL}

Middle school, as the link between primary school and high school, is particularly important in the whole process [4]. Junior high school English teaching is the focus of junior high school teaching, while English reading is the difficult point in English teaching. Reading, as a necessary English ability of junior high school students, needs to be cultivated and learned step by step.

However, many English teachers' teaching methods are single and backward. Although some junior middle school English teachers have rich teaching experience, they still use the teaching methods of more than ten years ago in the teaching process and occupy a dominant position in the classroom. For example, when I was an intern at a middle school in Taizhou, Jiangsu Province, I audited two grade two classes. It was found that the English teachers of the two classes adopted the hierarchical teaching method and the traditional teaching method respectively. The latter used the same questions in each lesson as in the introduction: What is it about? What is the central idea of the article? To some extent, this ignores students' acceptance and lacks interaction with students. Teachers in the classroom teaching means single, mainly based on "reading textbooks", the main teaching steps are to learn words -study the content of textbooks -- explain exercises after class. While the former often carefully designed each link of the text day according to the teaching steps of the open class stratified teaching, students will be divided into different levels, and perform according to the corresponding level, this paper introduces, let the foundation of poor students: in this article, do you have no understanding of the new words? For middle level students, the question is: What is the central theme of the passage? For the more able students, they were asked: Can you retell the story? In the final exam, the class that had been taught in a tiered way scored higher on average than the other class.

For teachers, the concept of hierarchical teaching and how to implement it are not clear. Layered this step for students, and most of the teachers can have a clear judgment, but many teachers in the teaching process for entrance pressure, and had to choose one of the most consistent with the exam-oriented education teaching method, is to instill a key, all the students a piece of paper, arranged from high to low, so often give students caused great psychological pressure. Therefore, the unequal relationship between students and teachers makes students always in the process of teaching in the passive side, it is difficult to actively participate in the interaction of teachers, so it requires teachers to change the teaching concept. Not only do the education of students, but also to make friends with students. The purpose of layered teaching is not to create a gap between teachers and students, but to help teachers understand students more comprehensively and objectively in this process, promote the common development of teachers and students, share learning experience and experience in the process of reading, and 
maximize the teaching effect. Teachers walk into students' hearts with sincere feelings, help students establish a good learning atmosphere and environment, so that students have more confidence in cooperative inquiry learning, and promote the success of layered teaching.

\section{SUGGESTIONS ON THE APPLICATION OF STRATIFIED TEACHING IN JUNIOR ENGLISH READING CLASS}

First of all, since teachers have been used to traditional teaching methods for a long time, they are confused about the use of layered teaching and don't know where to start. Therefore, it requires teachers to get rid of the disadvantages of traditional teaching thinking in the past, and to fully understand what is stratified teaching. In the process of popularizing the concept, in addition to the teachers themselves to the teaching method of learning (such as reading literature, and experienced teacher communication), school teachers training, make learning opportunities for teachers. In addition, in the process of application, it is not recommended that teachers follow the definition of layered teaching step by step, but flexibly arrange according to the situation of different classes, and gradually realize the meaning of layered teaching in practice.

In addition, there is another problem worth noting: many teachers cannot really implement layered teaching under the pressure of admission in the teaching process. Stratified teaching is very important to improve students' learning ability and improve the quality and efficiency of reading in reading class. However, the biggest obstacle to the implementation of layered teaching is the admission problem that both students and teachers need to face. In fact, traditional teaching is a method that teachers have to adopt under the background of high pressure of entering college, because it pays more attention to the emphasis and infusion of examination key points. In line with the principle of maximization of teaching effect, it repeats mechanical exercises for students of all levels in order to achieve good scores in the examination. However, the stratified teaching is somewhat contrary to the examoriented environment, because it pays more attention to the cultivation of students' ability, gradually cultivating students' interest in learning over a long period of time, and the process of improving scores is relatively slow. Especially for the reading class, the traditional teaching method is more inclined to teach students the vocabulary and syntax in the article, but does not pay attention to the cultivation of students' ability of intensive reading or skimming. Therefore, it has become the first learning method adopted by most teachers under the requirements of grades. This requires schools and teachers to improve the management method of stratified teaching and implement a flexible mechanism. The layers are not fixed, but should be adjusted every semester or academic year. The changes are mainly based on the students' learning situation. If they make significant progress, they can be raised, while if they have difficulty in learning, they can be lowered. In teaching, teachers set out from the reality of good, medium and poor students to determine the goals of different levels, carry out different levels of teaching and guidance, organize different levels of testing, so that all kinds of students get full development. Through investigation and observation, master the learning status, knowledge level, specialty, hobbies and social environment of each student in the class, and group the students according to their psychological characteristics to form a learning group. Make use of group cooperative learning and the form of mutual help and mutual learning between members, give full play to the interaction and motivation between teachers and students, and create opportunities for the overall development of each student. In particular, interpersonal interaction among students makes use of the differences and cooperative consciousness of students at different levels to form a collective power conducive to the coordinated development of each member.

At the same time, students will be motivated when they are divided into different levels. When the outstanding students are gathered together, the pressure of competition among them will increase. Because these students tend to have strong self-esteem, they will have better learning results due to the peer pressure. Therefore, stratified teaching model can promote the formation of a good learning atmosphere, and plays a role in motivating or warning students [6].

\section{CONCLUSION}

As a teaching method of junior high school English reading class, stratified teaching has great significance and value. For teachers, stratified teaching can not only help them to have a more comprehensive understanding of students' learning situation and learning level, but also improve their work efficiency and make them more flexible in lesson preparation, class and after class. Especially in the course of class, most of the contents learned in junior high school English reading class are based on daily situational dialogues and reading materials that are in line with the theme of each unit. For students, hierarchical teaching can help them learn knowledge better and do their best within their own ability. And through the guidance of teachers, set different tasks for students at different levels, which can not only improve students' confidence, but also improve their learning enthusiasm.

However, the use of hierarchical teaching still needs to rely on the accumulated experience of teachers to further practice in teaching, to become skilled in this 
teaching method. Stratified teaching is to divide students into different groups according to their learning level and learning ability and implement different teaching methods. But in practice, many schools divide students into key classes and ordinary classes according to their academic performance, which is not conducive to students' study. Schools need to correctly understand hierarchical teaching, abandon the wrong view of achievements, truly from the long-term development of students.

\section{ACKNOWLEDGMENTS}

I thank Yvonne and Chenkai for their helpful comments and advices for the outline and the earlier draft.

\section{REFERENCES}

[1] Yunlong Zhang, No. 14 Middle School, Shulan city, Jilin Province.

[2] Yan-kun Ma, Hao-sheng Ye, contemporary development of vygotsky's thought of recent development zone, Institute of Psychology, Nanjing normal University, Nanjing, 2004.

[3] Dan Lu, Guangfei Luo, Krashen I +1 Theory and Advanced English Audiovisual Teaching, Gannan Normal University, Ganzhou, Jiangxi, Vol.25, no.11.

[4] Catherine(Yongyang) Wang, On Chinese Culture Curriculum planning, International Education Journal, 2006, 7(4), 570-579.

[5] Karim Sadeghi, Self-reported teaching effectiveness and job satisfaction among teachers: therole of subject matter and other demographic variables, Urmia University, Iran.

[6] John Jerrima, Mary Oliverb, Sam Simsa, The relationship between inquiry-based teaching and students' achievement. New evidence from a longitudinal PISA study in England, UCL Institute of Education and Education Datalab, United Kingdom bUniversity of Nottingham, United Kingdom. 